\title{
The effects of different autumn-seeded cover crops on subsequent irrigated corn response to nitrogen fertilizer
}

\author{
Gholam Reza Mohammadi*, Mohammad Eghbal Ghobadi
}

Department of Crop Production and Breeding, Faculty of Agriculture, Razi University, Kermanshah, Iran; *Corresponding Author: mohammadi114@yahoo.com

Received 13 May 2010; revised 30 September 2010; accepted 3 October 2010.

\section{ABSTRACT}

A common crop rotation in the west Iran is wheat-fallow-corn. The fallow period after wheat harvest (during fall and winter) can lead to soil erosion, nutrient losses (e.g. nitrate leaching) and offsite movement of pesticides. This period is an ideal time to establish a cover crop. In order to investigate the effects of different autumn-bseeded cover crops on subsequent irrigated corn response to nitrogen fertilizer, field studies were carried out during the 2007-2008 growing season at the Agricultural Research Farm, Razi University, Kermanshah, Iran. The experiment was conducted in a split plot arrangement based on a randomized complete block design with three replications. The main plots consisted of four cover crops including alfalfa (Medicago sativa L.), berseem clover (Trifolium alexandrinum L.), common vetch (Vicia sativa L.) and winter rye (Secale cereale L.) and a control (no cover crop). The sub plots consisted of two fertilizer $\mathrm{N}$ rates $(0$ and $250 \mathrm{~kg}$ $\left.\mathrm{ha}^{-1}\right)$. Cover crops were grown for nearly 5 months and then were incorporated into the soil as green manures. The results indicated that corn plant traits including seed yield, the number of seeds per ear and leaf chlorophyll content were significantly influenced by cover crops. Whereas, the cover crops had no significant effects on the number of ears per plant, 100 -seed weight and harvest index of corn. Among the cover crop species, common vetch produced higher dry weight and showed the highest positive effects on the corn plant traits. Dry weight produced by this cover crop was $56.41,120.16$ and $124.19 \%$ higher than those of winter rye, berseem clover and alfalfa, respectively. Common vetch enhanced seed yield, the number of seeds per ear and leaf chlorophyll content of corn by $46.30,21.95$ and $8.52 \%$, respectively, compared to control. All of the corn traits under study, except the number of ears per plant and harvest index were significantly improved by nitrogen fertilizer. In general, this study revealed that the autumn-seeded cover crops, especially common vetch can be used to improve corn yield. However, the cover crops should be supplemented with nitrogen fertilizer to obtain optimal results.

Keywords: Corn; Cover Crop; Nitrogen Fertilizer

\section{INTRODUCTION}

A common crop rotation in the west Iran is wheat-fallow-corn. The fallow period after wheat harvest (during fall and winter) can lead to soil erosion, nutrient losses (e.g. nitrate leaching) and offsite movement of pesticides. In addition, weeds can germinate and grow without competition [1]. This period is an ideal time to establish a cover crop. Cover crops can be readily incorporated into crop rotations that include cereals [2]. A well-chosen cover crop can intercept raindrops and reduce water runoff, soil erosion and protect streams from pollution [1]. However, the protection that such vegetation provides against erosion is influenced mainly by the amount of biomass that covers the ground (differs with each spp) [3]. Cover crops have also been shown to increase the number of organisms which are natural enemies of some crop pests [1]. These crops offer habitat or resources for beneficial organisms $[4,5]$. For example, populations of ground-dwelling predators were greater in a corn and soybean rotation with alfalfa and kura clover cover crops than without a cover crop [6]. Studies focusing on legume cover crops establishment following cereals have reported considerable $\mathrm{N}$ contribution to a subsequent 
corn crop $[7,8]$.

Brophy et al. [9] suggested that when cover crops are turned over into the soil as green manures, they contribute nutrients to the main crop so that less chemical fertilizer required. However, the amount of the contribution depends on the biomass which varies over time and depends on rainfall and other factors. Lehman et al. [10] also noted that the legume cover crops have imported positive effects on the nutrient cycling in three ways: 1) recycling soil nutrients 2) enhancing soil nutrient availability for the main crop and 3) fixing the atmospheric $\mathrm{N}_{2}$ that is important for the main crop. However, crop yield responses to additional fertilizer $\mathrm{N}$ continue to occur in some environments and certain management systems $[11,12]$.

Nonlegume cover crops, primarily winter rye, are also used during the overwinter period to reduce wind erosion and potentially recover residual $\mathrm{N}$ from the soil or provide other benefits to subsequent crops [13]. Several studies [14-16] showed that significant amounts of $\mathrm{N}$ can be accumulated by nonlegume cover crops. Bundy and Andraski [13] reported that corn grain yields at below optimum $\mathrm{N}$ rates $\left(0\right.$ and $\left.112 \mathrm{~kg} \mathrm{ha}^{-1}\right)$ were significantly higher where the rye cover crop was grown. However, legume cover crop species are often preferable to nonlegumes because they supply their own N. In general, biological $\mathrm{N}$ fixation (for legumes) and overall $\mathrm{N}$ accumulation during growth are primary factors governing the adequacy of a cover crop as an $\mathrm{N}$ source. Moreover, genetic differences (species and variety) may dictate that some legumes grow larger and accumulate more $\mathrm{N}$ than others. Environment (temperature, soil type and nutrient and water availability) and management (e.g., planting density and timing, mowing, and pest control) may further alter performance of individual cover crop species [17-19]. Because they do not derive direct sales profit, cover crop species are often chosen that require acceptably low levels of nutrient, irrigation, and pest control inputs and often fit into otherwise unplanted fallow periods. However, despite the positive effects often produced by winter annual cover crops in corn production, there is also a potential for reduction in corn yield [20]. Therefore, the success of these kinds of cropping system is largely determined by the selection of the most appropriate cover crop species and there is no consensus as to which cover crops import more positive effects on corn yield.

The present study was conducted to evaluate the effects of different cover crops (non-legume and legume species) planted during the fallow period (after wheat harvest) on subsequent irrigated corn response to nitrogen fertilizer in the west Iran.

\section{MATERIALS AND METHODS}

The study was carried out during the 2007-2008 growing season at the Agricultural Research Farm of Razi University, Kermanshah, west Iran. The soil type was a silty clay with a $\mathrm{pH}$ of $7.9-8.3$ and $0.8 \%$ organic matter. The field was planted with wheat (Triticum aestivum L.) the previous growing season. The land was plowed and disked before crops planting. Fertilizers were applied according to the soil test recommendations. For all crops, irrigation was applied at germination and thereafter to prevent water stress. Weeds were controlled as needed during all of the growing season.

The experiment was conducted in a split plot arrangement based on a randomized complete block design with three replications. The main plots consisted of four cover crops and a control (no cover crop). The cover crop species evaluated were alfalfa (Medicago sativa L.), berseem clover (Trifolium alexandrinum L.), common vetch (Vicia sativa L.) and winter rye (Secale cereale L.). These cover crop species were selected according to environmental conditions and economic considerations of the region. Before corn planting, each main plot was split into two sub plots. The sub plots consisted of two fertilizer $\mathrm{N}$ rates $\left(0\right.$ and $\left.250 \mathrm{~kg} \mathrm{ha}^{-1}\right)$ applied in the form of urea. Cover crops were seeded on 12 October 2007 by surface broadcasting at seeding rates of $50 \mathrm{~kg} \mathrm{ha}^{-1}$ alfalfa, $50 \mathrm{~kg} \mathrm{ha}^{-1}$ berseem clover, $250 \mathrm{~kg}$ $\mathrm{ha}^{-1}$ common vetch and $220 \mathrm{~kg} \mathrm{ha}^{-1}$ winter rye. The seeding rate of each cover crop treatment was based on the recommended forage seeding rate for that crop in the region. Cover crops were grown for nearly 5 months and then were incorporated into the soil as green manures on 16 March 2008. Before incorporation cover crop dry weights were determined by harvesting them at ground level in three random $0.5 \times 0.5 \mathrm{~m}$ quadrats in each sub plot. Then cover crop plants were dried at $80^{\circ} \mathrm{C}$ to the constant weights and weighed.

The corn cultivar used was 'KSC 704' (a grain corn cultivar that is commonly planted in the region). In order to protect against soil-borne diseases, prior to seeding, the corn seeds were treated with benomyl at $0.2 \%(\mathrm{w} / \mathrm{w})$. Corn was planted in the sub plots on 2 May 2008. Each sub plot consisted of five corn rows of $5 \mathrm{~m}$ long with a row spacing of $75 \mathrm{~cm}$ and with $20 \mathrm{~cm}$ between plants in the same row. At tasselling stage leaf chlorophyll content of corn plants was determined on 10 randomly selected plants of each plot using a chlorophyll meter (SPAD-502; Minolta, Osaka, Japan).

At maturity, the corn plants located $2 \mathrm{~m}$ from the three center rows of each sub plot were harvested by hand, allowed to dry at $80^{\circ} \mathrm{C}$ to a constant weight, then threshed and seed yield $\left(\mathrm{g} \mathrm{m}^{-2}\right)$ was obtained and reported based 
on a moisture content of $15.5 \%$. Before final harvesting corn yield components including the number of ears per plant and the number of seeds per ear were determined on five randomly selected plants in the center rows of each sub plot. Additionally, 100-seed weight was measured according to the recommendation of the International Seed Testing Association (ISTA) [21]. Harvest index was calculated as the ratio of seed weight to total shoot weight [22]. The data analyses were carried out using SAS software [23].

\section{RESULTS AND DISCUSSION}

According to analysis of variance (data not shown) there was a significant difference (at the 0.01 level of probability) between the dry weights produced by different cover crop species under study. Moreover, corn plant traits including seed yield, the number of seeds per ear, 100-seed weight and leaf chlorophyll content were significantly influenced by nitrogen fertilizer treatment. Whereas, the effect of cover crop treatment was statistically significant for seed yield, the number of seeds per ear and leaf chlorophyll content. Both nitrogen fertilizer and cover crop treatments had no significant effects on the number of ears per plant and harvest index of corn. Moreover, the two way interaction (cover crop treatment $\times$ nitrogen fertilizer level) was not significant for all of the traits under study.

Among the cover crop species, common vetch produced higher dry weight at the time of the incorporation into the soil (Table 1). Dry weight produced by common vetch was 56.41, 120.16 and $124.19 \%$ higher than those of winter rye, berseem clover and alfalfa, respectively (Table 1). Alfalfa produced the lowest dry weight, although there was no significant difference between this cover crop and berseem clover for the dry weight produced (Table 1). Although, winter rye produced higher dry weight than those of berseem clover and alfalfa, but the corn plant traits were not significantly improved by this cover crop (Table 1). According to Ranells and Wagger [24] non leguminous cover crops typically have low $\mathrm{N}$ contents and high $\mathrm{C} / \mathrm{N}$ ratios, showing litter or no beneficial effects on the succeeding crop yield. As determined visually, common vetch also produced a dense canopy on the ground surface throughout the growing season. This can be attributed to the better establishment and growth of this cover crop under environmental condition of the region as compared with other cover crops under study. In temperate environments winter-hardy legumes such as vetch are capable of accumulating large amounts of biomass and $\mathrm{N}$ and delivering substantial $\mathrm{N}$ benefit to subsequent spring-planted crops [25].

All of the corn plant traits under study except the number of ears per plant and harvest index were significantly improved by nitrogen fertilizer applied at $250 \mathrm{~kg}$ $\mathrm{ha}^{-1}$ (Table 2). Overall, this treatment increased seed yield, the number of seeds per ear, 100-seed weight and leaf chlorophyll content by $61.24,96.83,12.05$ and $19.23 \%$, respectively, when compared with the treatment in which no nitrogen fertilizer was applied (Table 2). According to Thonnissen et al. [26] with respect to season and location, green manure $\mathrm{N}$ should be supplemented with $\mathrm{N}$ fertilizer to ensure optimal yields.

Among the cover crop species, common vetch showed the highest positive effects on the corn plant traits. This cover crop enhanced seed yield, the number of seeds per ear and leaf chlorophyll content by 46.30, 21.95 and $8.52 \%$, respectively, compared to control (no cover crop) (Table 1). However, the number of ears per plant, 100 -seed weight and harvest index of corn were not significantly affected by common vetch or other cover crops (Table 1). Moreover, there were no significant differences between other cover crops and control for

Table 1. Means comparison of the traits under different cover crop treatments.

\begin{tabular}{|c|c|c|c|c|c|c|c|}
\hline \multirow[b]{2}{*}{$\begin{array}{c}\text { Cover crop } \\
\text { treatment }\end{array}$} & \multicolumn{6}{|c|}{ Corn } & \multirow{2}{*}{$\begin{array}{l}\text { Cover crop } \\
\text { dry weight } \\
\quad\left(\mathrm{g} \mathrm{m}^{-2}\right)\end{array}$} \\
\hline & $\begin{array}{l}\text { Seed yield } \\
\quad\left(\mathrm{g} \mathrm{m}^{-2}\right)\end{array}$ & $\begin{array}{l}\text { Seeds per } \\
\text { ear }(\mathrm{N})\end{array}$ & $\begin{array}{c}100 \text {-seed } \\
\text { weight }(\mathrm{g})\end{array}$ & $\begin{array}{l}\text { Ears per } \\
\text { plant }(\mathrm{N})\end{array}$ & $\begin{array}{l}\text { Leaf chloro- } \\
\text { phyll content } \\
\text { (SPAD value) }\end{array}$ & Harvest index & \\
\hline Common vetch & 924.14 a & $548.61 \mathrm{a}$ & $24.92 \mathrm{a}$ & $1.02 \mathrm{a}$ & $53.51 \mathrm{a}$ & $0.39 \mathrm{a}$ & $306.29 \mathrm{a}$ \\
\hline Alfalfa & $734.49 \mathrm{~b}$ & $462.29 \mathrm{~b}$ & $24.03 \mathrm{a}$ & $1.00 \mathrm{a}$ & $47.20 \mathrm{bc}$ & $0.37 \mathrm{a}$ & $136.62 \mathrm{c}$ \\
\hline Berseem clover & $737.26 \mathrm{~b}$ & $448.76 \mathrm{~b}$ & $25.18 \mathrm{a}$ & $1.01 \mathrm{a}$ & $47.07 \mathrm{bc}$ & $0.37 \mathrm{a}$ & $139.12 \mathrm{c}$ \\
\hline Rye & $702.17 \mathrm{~b}$ & $449.89 \mathrm{~b}$ & $26.00 \mathrm{a}$ & $0.94 \mathrm{a}$ & $44.28 \mathrm{c}$ & $0.37 \mathrm{a}$ & $195.82 \mathrm{~b}$ \\
\hline $\begin{array}{l}\text { Control (no } \\
\text { cover crop) }\end{array}$ & $631.68 \mathrm{~b}$ & $449.85 \mathrm{~b}$ & $23.11 \mathrm{a}$ & $0.94 \mathrm{a}$ & $49.31 \mathrm{~b}$ & $0.37 \mathrm{a}$ & $000.00 \mathrm{~d}$ \\
\hline $\operatorname{LSD}(0.05)$ & 174.79 & 53.88 & 5.19 & 0.10 & 3.69 & 0.03 & 42.54 \\
\hline
\end{tabular}

The same letters at each column indicate an insignificant difference at the 0.05 level of probability. LSD, least significant difference; SPAD, refers to the chlorophyll meter. 
Table 2. Means comparison of corn plant traits under different nitrogen fertilizer levels.

\begin{tabular}{ccccccc}
\hline \multirow{2}{*}{$\begin{array}{c}\text { Nitrogen fertilizer } \\
\text { level }\left(\mathrm{kg} \mathrm{ha}^{-1}\right)\end{array}$} & $\begin{array}{c}\text { Seed yield } \\
\left(\mathrm{g} \mathrm{m}^{-2}\right)\end{array}$ & $\begin{array}{c}\text { Seeds per } \\
\text { ear }(\mathrm{N})\end{array}$ & $\begin{array}{c}100 \text {-seed weight } \\
(\mathrm{g})\end{array}$ & $\begin{array}{c}\text { Ears per plant } \\
(\mathrm{N})\end{array}$ & $\begin{array}{c}\text { Leaf chlorophyll } \\
\text { content } \\
(\text { SPAD value })\end{array}$ & Harvest index \\
\hline 250 & $920.80 \mathrm{a}$ & $623.16 \mathrm{a}$ & $26.04 \mathrm{a}$ & $0.99 \mathrm{a}$ & $52.51 \mathrm{a}$ & $0.38 \mathrm{a}$ \\
0 & $571.08 \mathrm{~b}$ & $316.60 \mathrm{~b}$ & $23.24 \mathrm{~b}$ & $0.97 \mathrm{a}$ & $44.04 \mathrm{~b}$ & $0.37 \mathrm{a}$ \\
LSD $(0.05)$ & 87.42 & 63.29 & 2.08 & 0.04 & 6.26 & 0.02 \\
\hline
\end{tabular}

Dissimilar letters at each column indicate a significant difference at the 0.05 level of probability. LSD, least significant difference; SPAD, refers to the chlorophyll meter.

seed yield and the number of seeds per ear of corn. Corn seed yields were improved by $16.71,16.28$ and $11.16 \%$ following berseem clover, alfalfa and winter rye, respectively, when compared with control, but theses improvements were not statistically significant (Table 1). Leaf chlorophyll content of corn was significantly lower in winter rye treatment than control, so that, this cover crop caused the reduction of $10.20 \%$ in leaf chlorophyll content of corn plant as compared with control (Table 1). This can be attributed to the higher $\mathrm{C} / \mathrm{N}$ ratio in plant tissues of non-legume cover crops such as winter rye [27] that consequently lead to the slower decomposition and $\mathrm{N}$ release of their plant tissues [28] and strong $\mathrm{N}$ immobilization after these crops are added as green manures into the soil [29]. This can result in reduced $\mathrm{N}$ availability to corn.

The enhancement of leaf chlorophyll content by common vetch can be due to the improved soil nitrogen condition by incorporated common vetch plants. This can be led to the increased leaf nitrogen content [30]. Nitrogen is a substantial element of the chlorophyll structure, so that, a positive correlation between leaf nitrogen and chlorophyll content is well documented for a number of plant species [31-34]. Moreover, the positive significant correlations between photosynthesis and leaf nitrogen content have been proved for a large number of species [35-40]. The improvement of photosynthesis due to increased leaf chlorophyll content ultimately can result in the enhancement of corn growth and yield.

Moreover, higher corn seed yield in the plots in which common vetch was incorporated into the soil can be as a result of the higher dry weight produced by this cover crop that consequently led to the improvement of soil condition and nutrient supplement to corn plants. This was supported by a significant and positive correlation between corn seed yield and cover crop dry weight $(\mathrm{r}=$ 0.67; $\mathrm{P}<0.01)$. According to Brophy et al. [9] when cover crops are turned over into the soil as green manures they contribute nutrients to the main crop. The amount of the contribution depends on the biomass which varies over time and depends on cover crop spe- cies and other factors.

Nitrogen fertilizer applied at the level of $250 \mathrm{~kg} \mathrm{ha}^{-1}$ increased corn seed yield by 129.03, 71.59, 59.08, 47.25 and $33.62 \%$ following control (no cover crop), winter rye, alfalfa, berseem clover and common vetch treatments, respectively, when compared with the treatment in which no nitrogen fertilizer was applied (Figure 1). In other words, nitrogen application improved corn seed yield following all of the cover crop treatments. However, the highest improvement occurred at the control plots (Figure 1). Moreover, there were lower corn seed yield responses to nitrogen fertilizer following legume cover crops than rye, so that, the highest and the lowest enhancements of corn seed yields due to the applied nitrogen fertilizer were obtained following winter rye and common vetch cover crops, respectively (Figure 1).

Overall, improvements of the corn plant traits in response to the applied nitrogen fertilizer indicated that the nitrogen released from the incorporated cover crops was not sufficient to support the potential corn growth and yield. Griffin et al. [41] also reported that cover crops can supply all or most of the $\mathrm{N}$ required by a subsequent crop if cover crop biomass is of sufficient quantity and $\mathrm{N}$ mineralization is approximately synchronous with sub

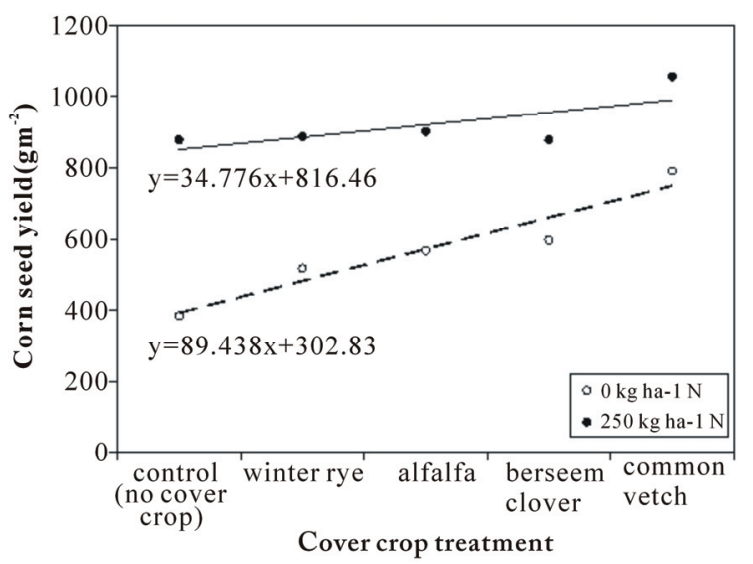

Figure 1. The effect of different cover crop treatments on corn seed yield under two nitrogen fertilizer levels $(0$ and 250 $\left.\mathrm{kg} \mathrm{ha}^{-1}\right)$. 
sequent crop demand. However, studies evaluating the effect of ${ }^{15} \mathrm{~N}$ from legume residues decomposing under field conditions lead to the conclusions that $<30 \%$ of legume $\mathrm{N}$ was recovered by a subsequent nonlegume crop and large amounts of legume $\mathrm{N}$ were retained in soil, mostly in organic forms [42-44]. Kuo and Jellum [45] also found that corn yields were affected by $\mathrm{N}$ fertilizer applied irrespective of cover crop species.

In general, this study revealed that the autumn-seeded cover crops, especially common vetch can be used to improve corn yield. However, the cover crops should be supplemented with nitrogen fertilizer to obtain optimal results.

\section{REFERENCES}

[1] Hartwig, N.L. and Ammon, H.U. (2002) Cover crops and living mulches. Weed Science, 50, 688-699.

[2] Vyn, T.J., Faber, J.G., Janovicek, K.J. and Beauchamp, E.G. (2000) Cover crop effects on nitrogen availability to corn following wheat. Agronomy Journal, 92, 915-924.

[3] Trohen, F. and Hobbs, J.A. (1991) Soil and water conservation. Prentice Hall Inc., Englewood Cliffs, 4, 83-84 and 5, 108-109.

[4] Bugg, R.L., Wackers, F.L., Brunson, K.E., Dutcher, J.D. and Phatak, S.C. (1991) Cool-season cover crops relay intercropped with cantaloupe: Influence on a generalist predator, Geocoris punctipes (Hemiptera: Lygaeidae). Journal of Economic Entomology, 84, 408-416.

[5] Nicholls, C.I. and Altieri, M.A. (2001) Manipulating plant biodiversity to enhance biological control of insect pests: A case study of a northern California vineyard. In: Gliessman, S.R., Ed., Agroecosystem sustainability: Developing practical strategies. CRC Press, Boca Raton, 29-50.

[6] Prafiska, J.R., Schmidt, N.P. and Kohler, K.A. (2006) Effects of living mulches on predator abundance and sentinel prey in a corn-soybean-forage rotation. Environmental Entomology, 35, 1423-1431.

[7] Bruulsema, T.W. and Christie, B.R. (1987) Nitrogen contribution to succeeding sweet corn from alfalfa and red clover. Agronomy Journal, 79, 96-100.

[8] Stute, J.K. and Posner, J.L. (1995) Legume cover crops as a nitrogen source for corn in an oat-corn rotation. Journal of Production Agriculture, 8, 385-390.

[9] Brophy, L.S., Heichel, G.H. and Russelle, M.P. (1987) Nitrogen transfer from forage legumes to grass in a systematic planting design. Crop Science, 27, 753-758.

[10] Lehman, J., da Silva, J.P., Trujillo, L., Jr. and Uguen, K. (2000) Legume cover crops and nutrient cycling in tropical fruit tree production. Acta Horticulturae, 531, 35-72.

[11] Dou, Z., Fox, R.H. and Toth, J.D. (1994) Tillage effect on seasonal nitrogen availability in corn supplied with legume green manures. Plant and Soil, 162, 203-210.

[12] Hesterman, O.B., Griffin, T.S., Williams, P.T., Harris, G.H. and Christenson, D.R. (1992) Forage legume-small grain intercrops: Nitrogen production and response for subsequent corn. Journal of Production Agriculture, 5,
340-348.

[13] Bundy, L.G. and Andraski, T.W. (2005) Recovery of fertilizer nitrogen in crop residues and cover crops on an irrigated sandy soil. Soil Science Society of America Journal, 69, 640-648.

[14] Ditsch, D.C. and Alley, M.M. (1991) Nonleguminous cover crop management for residual $\mathrm{N}$ recovery and subsequent crop yields. Journal of Fertilizer Issues, 8, 6-13.

[15] Ditsch, D.C., Alley, M.M., Kelley, K.R. and Lei, Y.Z. (1993) Effectiveness of winter rye for accumulating residual fertilizer $\mathrm{N}$ following corn. Journal of Soil and Water Conservation, 48, 125-131.

[16] Vaughan, J.D. and Evanylo, G.K. (1998) Corn response to cover crop species, spring desiccation time, and residue management. Agronomy Journal, 90, 536-544.

[17] Kouyate, Z., Franzluebbers, K., Juo, A.S.R. and Hossner, L.R. (2000) Tillage, crop residue, legume rotation, and green manure effects on sorghum and millet yields in the semiarid tropics of Mali. Plant and Soil, 225, 141-151.

[18] Ross, S.M., King, J.R., Izaurralde, R.C. and O'Donovan, J.T. (2001) Weed suppression by seven clover species. Agronomy Journal, 93, 820-827.

[19] Steinmaier, N. and Ngoliya, A. (2001) Potential of pasture legumes in low-external-input and sustainable agriculture (LEISA): I. Results from green manure research in Luapula Province, Zambia. Experimental Agriculture, 37, 297-307.

[20] Fisk, J.W., Hesterman, O.B., Shrestha, A., Kells, J.J., Harwood, R.R., Squire, J.M. and Sheaffer, C.C. (2001) Weed suppression by annual legume cover crops in notillage corn. Agronomy Journal, 93, 319-325.

[21] Draper, S.R. (1985) International rules for seed testing. Seed Science and Technology, 13, 342-343.

[22] McDonald, P.B., Singer, J.W. and Wiedenhoeft, M.H. (2008) Self-seeded cereal cover crop effects on interspecific competition with corn. Agronomy Journal, 100, 440-446.

[23] SAS Institute (1988) SAS/STAT, Guide for personal computer, Release 6.04. SAS Institute Inc., Cary.

[24] Ranells, N.N. and Wagger, M.G. (1996) Nitrogen release from grass and legume cover crop monocultures and bicultures. Agronomy Journal, 88, 777-782.

[25] Cherr, C.M., Scholberg, J.M.S. and McSorley, R. (2006) Green manure as nitrogen source for sweet corn in a warm-temperate environment. Agronomy Journal, 98, 1173-1180.

[26] Thonnissen, C., Midmore, D.J., Ladha, J.K. and Olk, D.C. (2000) Legume decomposition and nitrogen release when applied as green manures to tropical vegetable production systems. Agronomy Journal, 92, 253-260.

[27] Somda, Z.C., Ford, P.B. and Hargrove, W.L. (1991) Decomposition and nitrogen recycling of cover crops and crop residues. In: Hargrove, W.L., Ed., Cover Crops for Clean Water, Proceedings of an International Conference, Jackson, 9-11 April 1991, Soil Water Conservation Society, Ankeny, 103-105.

[28] Vigil, M.F. and Kissel, D.E. (1995) Rate of nitrogen mineralized from incorporated crop residues as influenced by temperature. Soil Science Society of America Journal, 59, 1636-1644.

[29] Mary, B. and Recous, S. (1994) Measurement of nitrogen 
mineralization and immobilization fluxes in soil as a means of predicting net mineralization. European Journal of Agronomy, 3, 291-300.

[30] Duiker, S.W. and Hartwig, N.L. (2004) Living mulches of legumes in imidazolinone-resistant corn. Agronomy Journal, 96, 1021-1028.

[31] Wu, F., Wu, L. and Xu, F. (1998) Chlorophyll meter to predict nitrogen sidedress requirements for short-season cotton (Gossypium hirsutum L.). Field Crops Research, 56, 309-314.

[32] Nageswara Rao, R.C., Talwar, H.S. and Wright, G.C. (2001) Rapid assessment of specific leaf area and leaf nitrogen in peanut (Arachis hypogaea L.) using a chlorophyll meter. Journal of Agronomy and Crop Science, 186, $175-182$

[33] Chang, S.X. and Robison, D.J. (2003) Nondestructive and rapid estimation of hardwood foliar nitrogen status using the SPAD-502 chlorophyll meter. Forest Ecology and Management, 181, 331-338.

[34] Mauromicale, G., Ierna, A. and Marchese, M. (2006) Chlorophyll fluorescence and chlorophyll content in field-grown potato as affected by nitrogen supply, genotype, and plant age. Photosynthetica, 44, 76-82.

[35] Boote, K.J., Gallaher, R.N., Robertson, W.K., Hinson, K. and Hammond, L.C. (1978) Effect of foliar fertilization on photosynthesis, leaf nutrition, and yield of soybeans. Agronomy Journal, 70, 787-791.

[36] Hesketh, J.D., Ogren, W.L., Hageman, M.E. and Peters, D.B. (1981) Correlations among leaf $\mathrm{CO}_{2}$-exchange rates, areas and enzyme activities among soybean cultivars.
Photosynthesis Research, 2, 21- 30.

[37] Lugg, D.G. and Sinclair, T.R. (1981) Seasonal changes in photosynthesis of field-grown soybean leaflets. 2. Relation to nitrogen content. Photosynthetica, 15, 138-144.

[38] Boon-Long, P., Egli, D.B. and Leggett, J.E. (1983) Leaf $\mathrm{N}$ and photosynthesis during reproductive growth in soybeans. Crop Science, 23, 617-620.

[39] Buttery, B.R. and Buzzell, R.I. (1988) Soybean leaf nitrogen in relation to photosynthetic rate and yield. Canadian Journal of Plant Science, 68, 793-795.

[40] Evans, J.R. (1989) Photosynthesis and nitrogen relationships in leaves of $\mathrm{C}_{3}$ plants. Oecologia, 78, 9-19.

[41] Griffin, T., Liebman, M. and Jemison, J., Jr. (2000) Cover crops for sweet corn production in a short-season environment. Agronomy Journal, 92, 144-151.

[42] Harris, G.H., Hesterman, O.B., Paul, E.A., Peters, S.E. and Janke, R.R. (1994) Fate of legume and fertilizer nitrogen-15 in a long-term cropping systems experiment. Agronomy Journal, 86, 910-915.

[43] Ladd, J.N., Amato, M., Jackson, R.B. and Butler, J.H. (1983) Utilization by wheat crops of nitrogen from legume residues decomposing in soils in the field. Soil Biology and Biochemistry, 15, 231-238.

[44] Mueller, M.M. and Sundman, V. (1988) The fate of nitrogen $\left({ }^{15} \mathrm{~N}\right)$ released from different plant materials during decomposition under field conditions. Plant and Soil, 105, 133-139.

[45] Kuo, S. and Jellum, E.J. (2002) Influence of winter cover crop and residue management on soil nitrogen availability and corn. Agronomy Journal, 94, 501-508. 